\title{
Tocharian B agent nouns in -ntsa and their origin
}

\author{
Louise S. Friis | ORCID: 0000-0001-5905-2196 \\ Universiteit Leiden, Leiden, The Netherlands \\ l.s.friis@hum.leidenuniv.nl
}

\begin{abstract}
The agent noun suffix in -ntsa belongs to a complex of Tocharian B agent noun formations, similar in form, function, and inflection. Of these, two suffixes are widely believed to be related to -ntsa: the productive agent noun in -ñca and the lexicalised agent noun in -nta. The suffix -ntsa forms occupational titles to eleven verbs in Tocharian B and can be reconstructed for Proto-Tocharian through comparison with Tocharian A. In this paper, it is argued that the suffix originated in the feminine of the PIE active participle in * $n t$. This is substantiated by the fact that several $n t s a$-nouns refer to primarily female professions, as well as the existence of the relic forms 'premtsa 'pregnant' and B lāntsa 'queen'. Furthermore, it is proposed that the masculine is reflected in the suffixes - $\tilde{n} c a$ and $-n t a$ and that the disintegration of gendered inflection in the participle led to its development into several agent noun formations.
\end{abstract}

\section{Keywords}

Indo-European - Tocharian B - agent nouns - participles - feminine gender

\section{Introduction}

In the past decade, a group of competing suffixes forming agentive nouns in the Tocharian languages has received increased attention. Not only is their exact synchronic interpretation disputed, but the debate surrounding their origins has even proved to be of importance to our reconstruction of PIE. ${ }^{1}$

1 PIE = Proto-Indo-European (including Anatolian), PT = Proto-Tocharian; TB = Tocharian B, $\mathrm{TA}=$ Tocharian $\mathrm{A}$; * after a form indicates an inferred nominative (singular); ${ }^{\circ}$ indicates part of a compound. 
Tocharian B

prs.-ñca, ${ }^{\text {a }}$ e.g., weșseñca 'speaker, speaking' prs./sbj.-nta, e.g., weñenta 'orator' sbj.-ntsa, e.g., wapāntsa 'weaver' sbj.-uca: e.g., kärsauca 'knower, knowing' prs.-uki: e.g., erșuki* 'evoker, evoking' prs.-mo, e.g., cämpamo 'being able'

\section{Tocharian A}

prs.-nt, e.g., kärsnānt 'knower, knowing' sbj.-nt, e.g., pekant 'painter'

sbj.-nts*; cf. wāpamts * 'weaver'b

prs.-m, e.g., cämpam 'being able'

a These agentive nouns are formed to either the present or the subjunctive stem, here indicated by superscript ${ }^{\text {prs. }}$ or ${ }^{\text {sbj. }}$

b The only TA form with this suffix, wāpaṃts * , is assured from the abstract wāpämtsune 'weaving' (YQ 1.21 a8).

A remarkable fact is that TB shows a significantly larger inventory than TA; $c$. Table $1 .^{2}$

In terms of attestation, TB prs.-ñca and TA prs.- $n t$ are by far the most numerous, and these two are therefore generally taken as equivalents in Tocharian scholarship. Although the suffixes resemble each other formally, the palatalization in TB prs.-ñ $c a$ excludes an exact phonological match. Additionally, it has been shown that both prs.-uki and sbj.-uca are functionally and syntactically equivalent to ${ }^{\text {prs. }}$ ñca in TB (Schaefer 1997; Itkin \& Kuritsyna 202O). These suffixes exist in the grey area between agent noun and participle (Dietz 1981: 13, 144), showing features of both word classes. Agent noun features include that they do not inflect for gender, that they have a substantival declension (cf. Table 2), and that they are found most often in substantival function (Peyrot 2017: 328-329). Participial features include the fact that they can occur in attributive position as adjectives, that they are sometimes modified by adverbs, and that they govern an object in the oblique (Fellner 2017). However, other transitive verbal nouns also govern an object in the oblique, e.g., the verbal abstract in $\mathrm{B}_{-}$lñe, $\mathrm{A}_{-}$lune which is purely substantival $\left(T E B_{1}: 187-188\right)$. In the present article, I will use the term 'agent noun' to refer to these formations with the caveat that their interpretation is not clear-cut. ${ }^{3}$

2 Sometimes forms in ${ }^{\mathrm{B}}$-tstse, ${ }^{\mathrm{A}}$-ts are included in discussions of agent nouns because of forms like ${ }^{\mathrm{B}}$ käryortstse 'merchant' and A amokäts 'artisan'; cf. Adams (2015: 142). It is however clear that these forms are secondary substantivizations of primarily denominal adjectives; cf. Fellner (2014a), Itkin \& Kuritsyna (2020: 83 fn. 1).

$3{ }^{\mathrm{B}}-m o,{ }^{\mathrm{A}}-m$ is generally accepted as an agentive verbal adjective and will be left out of the discussion here. 
TABLE 2 The agentive $a$-declension ${ }^{\mathbf{a}}$

\section{kaușeñca 'killer, killing'}

$\begin{array}{ll}\text { nom.sg. } & \text { kaușeñca } \\ \text { voc.sg. } & \text { kaușeñcai } \\ \text { obl.sg. } & \text { kaușeñcai } \\ \text { gen.sg } & \text { kaușeñcantse } \\ \text { nom.pl. } & \text { kaușeñcañ } \\ \text { obl.pl. } & \text { kaușeñcam }\end{array}$

a $T E B_{1}$ classifies it as adjectival (class II.1.3, $\S 233$ ), but the vocative singular in -ai and the genitive singular in -antse are both substantival features.

There are two TB agentive suffixes that form purely substantival agent

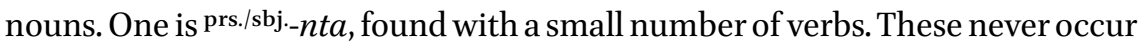
in attributive position, pace Fellner (2017: 77), and consist of lexicalised relics, sometimes found next to newer looking ñca-forms, e.g., weñenta $\sim$ weșseñca

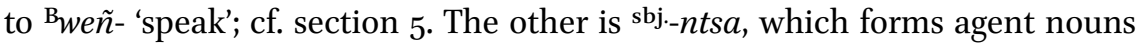
denoting occupations and seems to have been somewhat productive in the prehistory of TB. These two suffixes also share the agentive $a$-declension, as well as a remarkable similarity in phonological structure to the suffix prs.-ñca.

From an etymological point of view, a connection between the agent nouns with a formant in $/-\mathrm{NTa} /{ }^{4}$ and the PIE ${ }^{*} n t$-participle is obvious. This connection is mirrored by the existence of another verbal nominal, ${ }_{-}-m a n e,{ }^{\mathrm{A}_{-}}$mām, an exact formal match for the Indo-European middle participle * ${ }^{*} h_{1} n o ́-;$ cf.

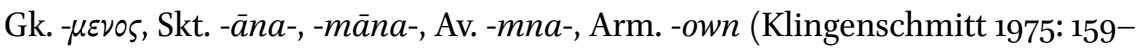
163). ${ }^{5}$ It is notable that neither ${ }^{\mathrm{B}}-\tilde{n} c a,{ }^{\mathrm{A}}-n t$ nor ${ }^{\mathrm{B}}-m a n e,{ }^{\mathrm{A}}-m \bar{a} m$ shows a synchronic affinity with active or middle voice. This has led scholars to conclude that they were not marked for voice in the proto-language until after Tocharian split from the rest of IE; cf. Melchert (1983: 24-25), Malzahn (2010: 480), Pinault (2012: 179). However, in the small group of verbs in Tocharian that show a semantic difference between active and middle, there is a clear tendency for ${ }^{\mathrm{B}}$-mane, ${ }^{\mathrm{A}}-m \bar{a} m$ to have the semantics of the finite middle, while forms with ${ }^{\mathrm{B}}-\tilde{n} c a,{ }^{\mathrm{A}}-n t$ always show semantics related to the finite active. ${ }^{6}$ This demon-

$4 \mathrm{~N}=n, \tilde{n}, m, \mathrm{~T}=t, c, t s$.

5 For the synchronic use and function of ${ }^{\mathrm{B}}$-mane, ${ }^{\mathrm{A}}-m \bar{a} m$, cf. Peyrot (2017).

6 The verbs in question are intransitive in the present middle and transitive in the present 
strates that at a prestage of Tocharian these forms were indeed assigned to middle and active voice respectively; cf. also Fellner \& Grestenberger (2018: 6869, 74-78).

The hypothesis that the agent nouns in /-NTa/ go back in some way to the PIE active participle in *-nt- raises new questions: why did they develop into agent nouns, ${ }^{7}$ why are there so many competing suffixes in TB compared to TA, and how are these are related within the history of Tocharian? In this article, I would like to present a new explanation for the origin of one of these suffixes, which in part answers all three questions.

\section{Occupational titles in -ntsa}

The occupational agent noun suffix -ntsa is given as - $(t) t s a$ in the handbooks of the 2oth century, mostly as part of a list of deverbal agent nouns; cf. Krause (1952: 47), TEB 1 (151), Pinault (1989: 83), Hilmarsson (1991: 124-125). Schmidt (2001: 20) proposed that the suffix was to be read -ntsa rather than -ttsa on the basis of Awāpämtsune 'weaving' (YQ $1.21 \mathrm{a} 8$ ), an abstract derived from an unattested A wäpämts ${ }^{*}$ "weaver'. The ligatures for $\langle$ ntsa $\rangle$ and $\langle$ ttsa $\rangle$ are quite similar; however, the spelling $\langle\underline{m t s a}\rangle$, equivalent to $\langle$ ntsa $\rangle$, is unambiguous. Since then, this interpretation has become the communis opinio. It has broken the link with what had previously been a core member of the class, ${ }^{\mathrm{B}}$ aknätsa, ${ }^{\mathrm{A}} \bar{a} k n a t s$ 'fool(ish)', which is always written with single $\langle$ tsa $\rangle$, never $\langle$ ttsa $\rangle .{ }^{8}$ On the other hand, the suffix can now be added to the group of TB agent noun suffixes with the phonological structure /-NTa/. The discovery of A wäpämtsune 'weaving' also meant that the suffix could reasonably be traced back to PT.

Since many of the ntsa-forms are attested only once or twice, their exact meanings are often hard to establish. Some can, however, be determined

active. These are ${ }^{\mathrm{B}} n ə k$-șa/se- 'destroy; mid. perish', ${ }^{\mathrm{B}} p a k$-șa/se- 'ripen, cook', ${ }^{\mathrm{B}} l u k$-ṣa/se- 'illuminate; mid. be illuminated', 'Btsək-ṣa/se- 'burn', Atäm-näsä/sa- 'beget, generate; mid. be born'. The intransitive meaning is found in ${ }^{\mathrm{B}}$ päksemane (THT $107 \mathrm{a2}$ ) 'cooking (itr.)', 'Btsäksemane (IOL Toch 5 a4) 'burning (itr.)', ' tmämsam( $\bar{a}) m$ (A $15^{2}$ b4) 'being born'. The transitive meaning is found in ${ }^{\mathrm{B}}$ äksseñca (PKAS $2 \mathrm{~B}$ a2, PKNS 48 a5, THT 30 a6, SI P 1 a3, THT 252 a2, THT 1919 b3) 'destroyer, destroying' and Atmämșant (A 292 a8) 'generating. The only counterexample is found in ${ }^{\mathrm{B}}$ nək-, to which the one attested mane-form in all likelihood is transitive: näksemane (9oK-58F-o1 a3) 'destroying'; cf. Ogihara (2015:150-152). Remarkably, all but one of these verbs have solid Indo-European etymologies; for ${ }^{\mathrm{A}} t a ̈ m-$, cf. Malzahn (2010: 654).

7 Unlike the preterite participle from the PIE perfect participle *-uos-, which remained adjectival; cf. Pinault (2008: 530-531), Peyrot (2010).

8 Whether the two are related farther back is still a subject for debate (cf. section 6). 
through Sanskrit parallels. One such form is tarkāntsa* (PK NS 107 b1) 'carpenter', which translates Skt. takșaka 'id.' (Thomas 1977:110). ${ }^{9}$ Another is waläntsa* 'hindrance', attested once in the oblique plural (THT 229 b1-b2), which corresponds to Buddhist Sanskrit nivvarana- 'disturbance, hindrance'. It is derived from ${ }^{B}$ wala- 10 'cover' with a semantic development similar to the Tibetan translation of the term: chod pa 'covering over' (Edgerton 1953: 311; Adams 2013: 631). The meaning of wapantsa 'weaver' is also beyond dispute. The derivational base is the verb ${ }^{\mathrm{B}}$ wapa- 'weave' (sbj.[5], prt.[1]). It is attested once in a fragment of the Jyotișka-Avadāna in THT 1165+1548 b2 (Ogihara 2012: 113) and thrice in THT 375 (a2, a4, b2), in apposition to the male personal name Varddhane as a professional title. A possible fifth attestation is wawānntsa, found in a cave inscription in Qizilgaha (Kg-O25-ZS-R-o1 2; cf. Ching \& Ogihara 2020: 275).

The form taktsāntsa (U 5208 a7-a8) is interesting, especially from an IndoEuropean perspective, since it has long been connected to Skt. tákșaṇ-, Gk. $\tau \varepsilon \dot{x} \tau \omega \nu$ 'carpenter'; cf. K.T. Schmidt apud Mayrhofer (1992: 614) and J. Schindler apud Ringe (1996: 4). It is translated by Schmidt as 'einer, der etwas kann'. Accordingly, Ringe (l.c.) argues that the form might be influential in the understanding of so-called thorn-clusters in Tocharian; it must be a very archaic form to which the base verb has been lost. The form is found in a TB-Old Uyghur bilingual. The Old Uyghur equivalent of the form reads $\langle\mathrm{u}-\breve{c} \mathbf{l}>$, restored by Maue (2015: 505) to udačı, a present participle in -dačı with agentive meaning (Clauson 1972: 2). This would have meant 'einer, der etwas kann; Könner' to the verbal root $u$ - 'be capable'. It is highly likely that Schmidt's proposed meaning of the Tocharian form is based on the same restoration of the Old Uyghur. However, in the edition of the bilingual, Peyrot, Pinault, \& Wilkens (2019: 79) argue that the lacuna in the Old Uyghur form is too big for the single akșara $<\mathrm{da}>$ and restore instead $u v d a c ̌$, likewise a present participle, but to the verb $u v$ - 'crush, crumble."11 The Tocharian form would thus be an $n t s a$-form from the root ${ }^{B}$ taksa- 'destroy, smash' with $t$-epenthesis possibly meaning 'crusher, grinder', which also on semantic grounds would be more attractive as an occu-

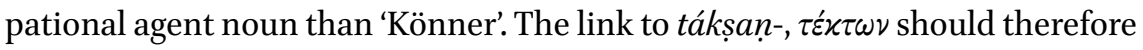
be given up.

9 Although the meaning is reasonably assured, the exact verbal base of this form is disputed. Thomas (l.c.) suggests ${ }^{\mathrm{B}} t \ddot{a r k}$ - 'twist', but since this root is not $a$-final, Malzahn (2010: 486) proposes a new root ${ }^{\mathrm{B}}$ tarka- 'do carpentry vel sim.'

10 For the vowels in TB in attested or inferred forms, I use the standard conventions: $\bar{a}$ indicates /á/, $a$ indicates $/ \mathrm{a} /$ or /á/, and $\ddot{a}$ indicates / / /. In verbal roots, I use-ə- and - $a$ - following the convention in Peyrot (2013).

11 According to Wilkens (2021: 784), other instances of udačı should be taken as mistakes for udčı 'cowherd'. 
The meanings of the forms without extra-Tocharian parallels have to be determined purely on the basis of their derivational base verb. These forms are most commonly found in monastery accounts and often in very fragmentary contexts. First off is naskāntsa * 'spinner'. It is attested once in THT $2718 \mathrm{a} 6$ and its meaning is determined on the basis of Bnaska- 'spin' (Pinault apud Ching 2010: 266). The attested form is remarkable because it shows the feminine plural ending -na with the addition of the genitive plural -ṃs:

\section{/// [na]s[ka]tsānaṃs cokiśṣalywe wsāwa șan்k /// THT 2718 a6}

'I gave lamp oil to the spinstresses: 1 pint'

The ending -na makes plurals exclusively to feminine nouns (TEB $B_{1}$ : 12O-121). It is probably in analogy to feminine nouns with the same declension (nom.sg. $-a$, obl.sg. -ai, nom-obl.pl. -ana) that -ntsa forms acquired this ending to explicitly mark the feminine plural. Since there is no separate feminine singular to $-n t s a$ and the regular plural -añ is not overtly marked as masculine, the ending functions in an almost derivational way: nom.pl. naskantsañ "spinners', but nom.-obl.pl. naskantsāna* 'female spinners, spinstresses'. The same ending is found with ${ }^{\mathrm{B}}-\tilde{n} c a$ : e.g., f.pl. yamașseñcana (IOL Toch 257 b2) to ${ }^{\mathrm{B}}$ yam- 'do', f.pl. enkașeñcana (THT 1107 b5) to ${ }^{\mathrm{B}}$ enk- 'seize'.

A recently discovered $n t s a$-noun is paikāntsa, attested twice in a Qizil cave inscription (Kz-181-ZS-Z-o1; cf. Ching \& Ogihara 2020:109). Clearly derived from the verb ' In line 1 , it is found in the nominative singular in apposition to a male personal name: paikāntsa Raktasene 'the painter Raktasene'. In the second line, we expect a comitative plural, but find a corrupted form instead: șkas paikāntsäm$p a$ 'along with six painter(s)'.

The word sarāntsa* is attested once in the genitive plural (Tumšuq 97 a2a3); cf. Pinault \& Ogihara (2010:185). It is quite likely derived from the verb ${ }^{\mathrm{B}}$ sar'plant' and could therefore mean 'planter' (or possibly 'gardener'?).

For warwāntsa*, attested five times in the perlative singular warwantsaisa (Ching 2010: 251), it is more difficult to determine the meaning as there are several candidates for the base verb: ${ }^{\mathrm{B}} w a r p a-$ 'receive, enjoy,, ${ }^{2} \mathrm{~B}_{w a r p a-}$ 'sur-

12 The texts in which warwantsaisa is found are late, so the change -rp- >-rw- would be regular for both ${ }^{\mathrm{B}_{w}}$ wrpa- and ${ }^{\mathrm{B}}$ warpa- (Peyrot 2008: 88). If to ${ }^{\mathrm{B}}{ }_{\text {warpa-, }}$ the spelling 〈wa $\rangle$ for expected $\langle$ wä $\rangle$ must be a scribal error. That it could be "built from the root-stressed subjunctive" (Adams 2013: 630) seems unlikely, since most other $n t s a$-forms are in fact built to root-stressed subjunctives of class [5], yet show medial accent. 
round', or ' 'warwa- 'be urged'. Adams (2013: 630) makes a good case for the first option, suggesting that the warwäntsa* was a receiver of goods. This fits well with use of the perlative, which can be translated 'through' or 'by way of':

warwantsaisa cokașe șalywe wsā (wa)

THT 2718 a5

'I gave lamp-oil by way of the [monastery's] receiver of goods' tr. ADAMS; his brackets

The form sparttämtsa is found once in THT $55^{8}$ a2. It is derived from ${ }^{\mathrm{B}}$ spartta- 'turn (itr.); behave', to which also the noun ${ }^{\mathrm{B}}$ spārtto 'discipline' is formed. Adams (2013: 783), followed by Itkin \& Kuritsyna (2020: 90), translates ' \pm scrupulous person' in the sense "one who behaves hypercorrectly." In the passage, however, it seems to refer to a person who practises asceticism habitually, rather than someone who only does it for show to receive gifts from laymen; cf. Chen (2019: 224-226).

ompostäm sparttāṃtsa sū pañäkte kä-a3sș̣intse palsko yänmāṣṣeñca mäsketrä

$$
\text { THT } 55^{8} \text { a2-a3 }
$$

'[If] afterwards [he is] a practitioner [of discipline], he becomes an achiever of the mind of the Buddha teacher'

The form mall [a]ntsasmem (THT 4062 a1) was first identified by Schmidt (2001: 2O-21) who translates 'vintner' (German 'Kelterer, Winzer'). He suggests that

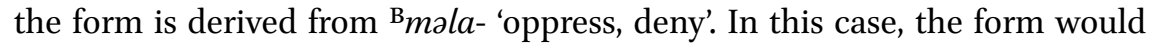
show an archaic semantic step between PIE * melh $_{2}$ - 'grind, mill' (cf. Hitt. malla- ${ }^{i}$, Lat. molō, Got. malan 'id.') and Tocharian. Subsequently, however, it has been established by Ching (2013:69) that the text does not pertain to winemaking, so it is quite unlikely that mallāntsa* would mean 'winemaker'. Another major problem with the form is of a morphological nature. The form clearly contains the ablative case suffix ${ }^{\mathrm{B}}-\mathrm{mem}$, preceded by $-s$-. In Tocharian, the secondary case suffixes such as the ablative are added to the oblique stem. If the form is an $n t s a$-form, one would expect either singular tmallantsaimem or plural †mallantsammem; $\mathrm{cf}$. the discussion in Ching (l.c.). Unfortunately, that means that both the morphological analysis and the exact semantics of the word are beyond our reach at the moment. 
An interesting case is tällaikāntsa*, found twice in monastery records. The derivational base does not correspond to any known verb, as verb bases are rarely trisyllabic. Instead, it has been suggested that the word is a compound with an $n t s a$-form as final member. Adams (2013: 315) suggests that the first member is tälle 'burden', compounded with 'ikantsa to the verb ${ }^{\mathrm{B}} i$ - 'go' to mean 'burden-goer' $\rightarrow$ 'porter'. Similarly, Malzahn (2010: 487) proposes tälleaikāntsa 'burden-knower' to ${ }^{\mathrm{B}}$ aik- 'know'. Elsewhere, the noun tälle 'burden'

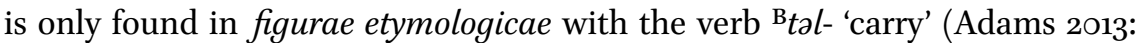
300). In the following passage, Adams (2013: 315) restores a genitive plural tällaik $[a] n t s[a m t s]$ and translates "five women of the porters". In the manuscript, however, there does not seem to be room for an extra akșara $\langle$ ts. $\rangle$ (cf. Ching 2010: 284), so a restoration to oblique plural is preferable:

ikäṃ ñune piś tällaik[a]nts[aṃ] tlaiyn $(a)^{13} / / /$

THT 484 a2

'On the 29th (day), five tällaikāntsa-women ...'

A third possibility would be to segment the form differently: täl-laikäntsa. In this case, the $n t s a$-form would be derived from the verb ${ }^{\mathrm{B}}$ laika- 'wash' compounded with an unknown first element $t \ddot{a} l^{\circ}, t a ̈ n^{\circ}$, or $t a ̈ r^{\circ}$.

Another possible case of a compound $n t s a$-form is $k(e)$ wyomntsai, likewise found in the monastery records (THT 2694.2). Ching (2010:242, 40O-401) identifies it as an occupational title next to a female personal name: /// $k \cdot$ wyomntsai Sumapriśkai $[\mathrm{m}] n(\mathrm{em})$ /// 'from Sumapriśka, the X'. Ching \& Ogihara (2010: $97 \mathrm{fn}$. 43) suggest that the word consists of $k e_{u}$ 'cow' and an $n t s a$-form to the verb Byənm- 'get' and propose the meaning 'cattle-keeper'. If this is the case, this passage would be clear evidence that $n t s a$-forms can have feminine reference as well as masculine much like ñca-forms; cf. the masculine varddhanem wapāntsai (obl.sg., THT 375 b2) 'Varddhane the weaver'. However, it is not completely clear how they arrive at the suggested meaning considering the meaning of Byənm- 'get, obtain, reach'.14 G.-J. Pinault apud Ching (2010: $401 \mathrm{fn}$.

\footnotetext{
13 tlaiyna should be read klaiyna obl.pl. 'women' (Sieg \& Siegling 1953: 302).

14 An interesting suggestion from one anonymous reviewer is that the second member is derived from ${ }^{\mathrm{B}} \mathrm{au}-n$ - 'hit, pierce' with the compound meaning 'cattle-prod'. This would necessitate the adjective kewiye 'bovine' as first member since the - $y$ - of the form would otherwise be unexplained. However, a derived adjective in this position would be quite unusual in TB grammar, making the suggestion less likely than that of Ching \& Ogihara (2010: 97 fn. 43); cf. Adams (2017: 1378-1379) for Tocharian compounds in general. ${ }^{\mathrm{B}} \mathrm{ka}_{u} \mathrm{rsse}$,
} 
91) offers another interpretation, namely that $k(e)$ wyomntsai is the feminine oblique singular of an adjective kewye ${ }_{u}^{*}$, showing the late TB sound change -aun- > -omn- (Peyrot 2008: 52). ${ }^{15}$ In that case, it would probably have been derived from the adjective kewiye 'bovine; butter', found several times in the monastery records as kewye, rather than directly from $k e_{u}$ 'cow'. Semantically, this would fit quite well with the translation 'cattle-keeper' in light of the pair yenme 'gate' $\rightarrow$ yenme $_{u}$ 'gatekeeper' (Adams 2013: 546). Ching \& Ogihara (l.c.) identify the title later in the same text, this time in apposition to a man Sumaiyśe*: [k]e $\cdot[o]$ (THT 2694.8). If this reading is correct, it would be an argument in favour of the $n t s a$-interpretation, since the masculine oblique of an adjective in $-e_{u}$ should end in -ent and thus cannot have an $o$-vowel. However, the passage is too broken to be definitive, and on semantic grounds, Pinault's suggestion is preferable.

In the end, $11 n t s a$-forms may be considered reasonably certain:

\begin{tabular}{|c|c|c|}
\hline $\begin{array}{l}\text { - wapāntsa } \\
\text { cf. A } \text { wāpäṃtsune 'weaving’ }\end{array}$ & 'weaver' & $\begin{array}{l}\text { THT } 1165+1548 \text { b2, } \\
\text { THT } 375 \text { a2, a4, b2, Kg-O25- } \\
\text { ZS-R-O1 } 2\end{array}$ \\
\hline - naskāntsa* & ‘spinner’ & THT 2718 a 6 \\
\hline - tällaikāntsa & '?-washer (?)' & THT 444 a, THT 4842 \\
\hline - taktsāntsa & 'grinder (?)' & $\mathrm{U}_{5208} \mathrm{a} 7-\mathrm{a} 8$ \\
\hline - paikāntsa & 'painter' & Kz-181-ZS-Z-o1 1, 2 \\
\hline - tarkāntsa* & ‘carpenter’ & PK NS 107 b1 \\
\hline - walāntsa* & 'hindrance' & THT 229 b1-b2 \\
\hline - sparttāṃtsa & 'practitioner' & THT $55^{8}$ a2 \\
\hline - mallāntsa* & '(op)presser (?)’ & THT 4062 al \\
\hline - sarāntsa* & 'planter (?)' & Tumšuq 97 a2-a3 \\
\hline - warwāntsa* & 'receiver (?)' & $\begin{array}{l}\text { THT } 26878, \text { THT } 27185, \\
\text { THT2722A } 2 \text {, THT } 28424 \text {, } \\
\text { THT } 28432\end{array}$ \\
\hline - kewyomntsa*? & 'cattle-keeper (?)' & THT 2694.2 \\
\hline
\end{tabular}

\footnotetext{
Akayurs 'bull' could be a compound containing the underived word for 'cow': *kew-warșe lit. 'cow male' (Hackstein 2017: 1306), if not from an inherited PIE syntagm * ${ }^{w}$ ous urseēn (Chen 2015).

15 For the inflection of adjectives in $-e_{w}$, cf. Table 3 below.
} 
It is generally accepted in Tocharian scholarship that the agent noun suffixes in -nta, -ñca and -ntsa are based in one way or another on the PIE * $n t$-participle; cf. Malzahn (2010: 488-491), Hackstein (2012), Pinault (2012), Fellner (2014b), Adams (2015: 140). It is also commonly agreed that for -ntsa a PIE phonological sequence * $n t i h_{2}$ is by far the best option as it would regularly give Pre-PT *-ntya $>\mathrm{PT}^{*}$-ntsa. In 2012, both O. Hackstein and G.-J. Pinault proposed derivational solutions to explain the morphological structure of this sequence.

Hackstein's (2012) solution is the more extensive of the two. He proposes that TB agentive suffixes go back to collectives in * $h_{2}$ originally from * $n t$-participles, some by way of $i$-abstracts (Hackstein 2012: 167-168):

$$
\begin{array}{ll}
--n t a & <{ }^{*}-n t-e h_{2} \\
--\tilde{n} c a & <{ }^{*} n t-i i-e h_{2} \\
--n t s a & <{ }^{*} n t-i-h_{2} \\
--t s a & <{ }^{*} t-i-h_{2} \\
--c a & <{ }^{*}-i i i-e h_{2}
\end{array}
$$

The fact that these formations do not inflect for gender is to Hackstein an indication that the collective suffix $*-h_{2}$ had only begun its development into a feminine suffix at the time Tocharian split from the Indo-European family tree. This solution relies on the development of collective-abstracts to agentive nouns on a large scale, described by Hackstein (2012: 164) as a "diachronic tendency or "drift" in Tocharian." This is rightly criticised by Fellner (2014b: 6o62 ), who points out that individualizations of abstract nouns usually happen on a lexical, not on a morphological basis, and that the examples used by Hackstein as parallels all retain their original abstract meaning side by side with the new agentive use, e.g., Germ. Bedienung 'service, server', OFr. justice 'justice, judge.' ${ }^{16}$ Lastly, the fact that Tocharian shows inherited gendered inflection in the preterite participles, using the formant ${ }^{*}-i h_{2}$ to mark the feminine, makes it quite likely that other participles showing this suffix were also inflected for gender; cf. TB m.nom.sg. yāmu, f.nom.sg. yāmusa < PIE *-ūos, *-usih ${ }_{2}$ (Pinault 2008: 530; Peyrot 2010).

Pinault (2012) proposes two possible etymologies for - $n t s a$. In the first solution (Pinault 2012: 187-188), he suggests that the word PT *aknatsa 'fool(ish)'

16 There is also a phonological problem with the variants in *-eh ${ }_{2}$ posited by Hackstein which should give ${ }^{\mathrm{B}_{-}-}$, not $^{\mathrm{B}}-a$ (Pinault 2012: 188-189; Fellner 2014b: 6o). 
could have been reanalysed as a participant noun ${ }^{17}$ pertaining to ability: 'one who is unable to understand'; cf. section 6 . From there, ${ }^{*}$-tsa was extracted and added to the stem of the * $n t$-participle. These forms then developed the specific meaning of an occupational suffix: "wapant-tsa 'one who is able to weave' $\rightarrow$ 'one who weaves professionally'. Since Pinault takes *aknatsa as an original collective abstract 'ignorance' (PIE *n-ǵne $\left.h_{3}-t i-h_{2}\right)$, there are at least three nontrivial semantic developments required by this hypothesis, not all of which are backed up by typological parallels. His second solution (Pinault 2012: 188-189) compares the $n t s a$-suffix to Hittite nouns in -anzan-, which seem to go back to *-nt-i-ön (Melchert 2003). This solution is supported by Fellner (2014b: 62-63). The advantage of the * $\bar{o} n$-suffix is that it is individualising in function, so the leap to agent noun is a short one. However, analogy is needed to explain the

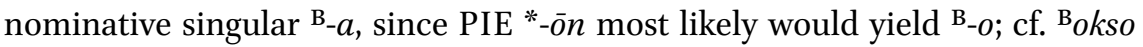
'ox' $<$ PIE *uksōn. ${ }^{18}$

\section{The origin of $n$ tsa-nouns}

I would like to present an alternative explanation for -ntsa and the other agent noun suffixes. It begins in a different area of TB nominal morphology, namely the adjectives in ${ }^{\mathrm{B}}-\bar{a}_{u}$ and ${ }^{\mathrm{B}}{ }_{-} e_{u}$ originally from PIE *uont-stems; cf. Table 3 . This paradigm shows us what we could have expected if the PIE *nt-participle had been continued without detours into Tocharian. What is remarkable is that the paradigm shows the same three phonological variants as the agent nouns; compare -nta with the m.obl.sg. -nt, -ñca with the m.nom.pl. -ñc, and -ntsa with the f.nom.sg -ntsa, obl.sg. -ntsai.

A look at the occupational ntsa-nouns suggests that it might not be a coincidence that the variant -nts- is found in the feminine singular of ${ }^{\mathrm{B}}$ tall $\bar{a}_{u}$ and ${ }^{\mathrm{B}}$ perne $_{u}{ }^{19}$ Among the $n t s a$-forms are occupations that are partly or fully undertaken by women, such as wapāntsa 'weaver' and naskāntsa* 'spinner'. The same

17 Cf. Haspelmath (1994: 171): "Participant nouns like agent nouns (e.g. writ-er), patient nouns (e.g. employ-ee), place nouns (e.g. Greek théa-tron 'theater', lit. 'lookingplace'), etc., are among the best-known examples of derivational morphology, showing frequent formal and semantic idiosyncrasies."

18 Cf. the discussion in Del Tomba (2020: 141-142). For a different viewpoint, see Jasanoff (2018).

19 With the identification of A wāpämtsune 'weaving', Ji, Winter, \& Pinault (1998: 148) also noticed this formal identity, as they suggested that the abstract was derived from a feminine term for 'weaver', "wäpamts. Since the masculine at this point was assumed to be A†wäpats, the connection to the *nt-participle was not made. 
m. f.

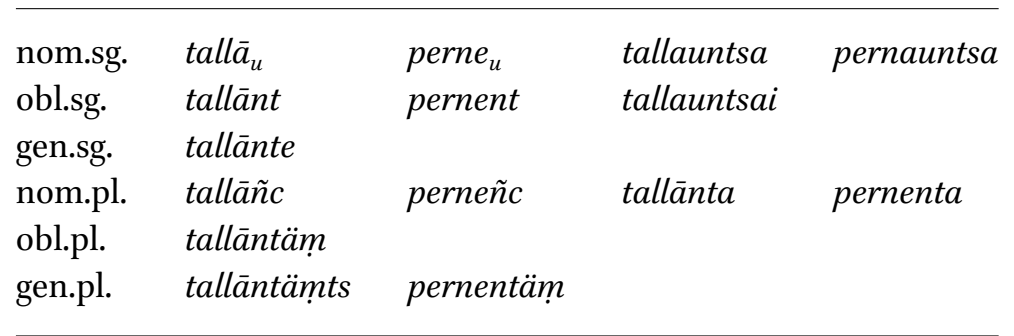

is probably true of tällaikāntsa*, especially if it is derived from ${ }^{\mathrm{B}}$ laika- 'wash'. In any case, the attestation of the form in THT 484 a2 indicates that women could be tällaikāntsas, whatever the exact meaning. A more tentative addition could be taktsāntsa 'grinder (?)', if this perhaps pertains to kitchen terminology. Such a suggestion is not out of the question, since the Old Uyghur verb $u v$ - 'crush, crumble' mentioned above is found in relation to food: ol etmek uvd '(s)he crumbled the bread'; cf. Clauson (1972: 4-5). With this in mind, as well as the phonological identity of the forms, the simplest solution in my opinion is to derive the $n t s a$-agent nouns from the feminine singular of the PIE * $n t$ participle.

Besides the occupational titles in -ntsa, there are two strong arguments in favour of this hypothesis: the first is the word for 'queen', the second the word for 'pregnant'. It is a longstanding hypothesis that the words for 'king', Bwalo, A wäl, and 'queen', Blāntsa, ${ }^{\mathrm{A}}$ lāmtsts, are relics of an athematic * $n t$-participle to a root aorist *uélH-/ullH- 'control'; cf. Van Windekens (1979: 554), Lubotsky (1994), Adams (2013: 631). These forms must have been lexicalised very early to have avoided any subsequent changes that happened in the participles. The word for 'queen' is therefore in my view direct evidence that Tocharian continued the feminine ${ }^{*} n t$-participle in the familiar shape ${ }^{*}-n t-i h_{2} \cdot{ }^{20}$

The second word Bpremtsa carries even more promise, although it is much more disputed. In early scholarship, it was taken as an adverb meaning 'instantly', derived from the noun 'prentse 'instant, moment'; cf. Couvreur (1955: 224), Sieg (1955: 76). Arguing that the word is found exclusively in medical texts, ${ }^{21}$ including one pertaining to 'Frauenkrankheit', Schmidt (1975: 294) pro-

20 For the inflection of ${ }^{\mathrm{B}}$ lāntsa, ${ }^{\mathrm{A}}$ lämts; cf. Del Tomba (2020: 69-70).

21 IOL Toch 306 b5, W 33 a6, THT 505 a2, a5-b1, b4. 
posed that premtsa is rather an adjective meaning 'pregnant'. From this analysis, he proposed a lantsa-type etymology of the form, namely that premtsa is the feminine of the $n t$-participle to the PIE verb ${ }^{*} b^{h} e r$ - 'carry' and is thus directly

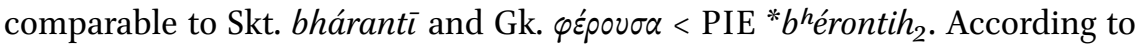
Schmidt (l.c.), there is also one instance showing a secondary meaning 'sexually potent (of a man)':

\section{///22 tso ${ }^{23}$ staukkanatär-me śle yasar kalträ klainats preṃtsa ynāñm yamasträ \\ IOL Toch 306 b5}

'(Nicht) wird der Penis ihnen schlaff, [sondern] steht mit Blut: Von den Frauen wird er [als] potent [zeugungsfähig] geschätzt.' tr. SCHMIDT 1975: 294; his brackets

However, Carling (2003) has conclusively shown through comparison with Sanskrit parallels that the passage in question pertains to the symptoms of uterine cancer (Skt. raktagulma-).

'their [i.e. of the women] abdomen grows, likewise the [menstrual] blood stands still [i.e. is obstructed]. It [i.e. the raktagulma symptoms] is evaluated by the women as if [they are] pregnant.'

tr. CARLING 2OO3: 91; her brackets

Thus, premtsa means only 'pregnant' and does not refer to male potency. It is noted by Carling (2003: 88) that it is problematic that premtsa as an adjective does not show agreement with the other constituents in the sentence. On those grounds, she questions Schmidt's etymology and instead presents an etymology by G.-J. Pinault, namely that premtsa is a perlative of an other-

22 Schmidt (1975: 293) restores $m \bar{a}$ 'not' at the beginning of the passage.

23 Couvreur (1955: 223-224) restores $(k \bar{a})$ tso 'abdomen'. However, the word is repeated in the next sentence without room for an extra akșara $\langle\mathrm{ka}\rangle$ : mäntakno tso erkatse 'further the tso is burning hot' (on erkatse, cf. Carling 2003: 89-9o, 93). Following Winter (1962: 113 fn. 10), Schmidt (1975: 293) argues for an independent word meaning 'penis' and bases his translation on this. Carling (2003: 86-87) rightly rejects this meaning and instead proposes an independent noun ${ }^{\mathrm{B}}$ tso, obl.sg. tsai meaning '(lower) abdomen'. It is, however, already suggested by Couvreur (1955: $223 \mathrm{fn}$. 10) that the second tso could be an orthographical mistake: "Ob für kātso mit ausgefallenem Akșara kā." F. Dragoni (p.c.) suggests that the copyist could have accidentally left out $k \bar{a}$ because of the graphic similarity of the akșaras kno and tso. 
wise unattested noun "prem 'plainness'; cf. Bemprem 'true'. The use of premtsa to mean 'pregnant' would thus be metaphorical in origin. However, the problem of agreement can be circumvented with a slight alteration in the interpretation of the passage, if one accepts that it is the (medical) patient, not the symptom of the tumour, who is the subject of ynāñm yamasträ 'is evaluated, is deemed':

///tso staukkanatär-me śle yasar kalträ klainats premtsa ynāñm yamasträ IOL Toch 306 b5

'Their stomach grows, likewise the blood stands still. She is deemed by the women to be pregnant.'

Elsewhere in the text, the patient is referred to both in the singular and the plural, so the change in number in this line is understandable; compare line $\mathrm{b}_{5}$ tso staukkanatär-me 'the stomach grows for them (pl.)' with line b6 ãnme șpä mäsketär-ne 'and desire arises for her (sg.)'. Schmidt's analysis of the form as an adjective from a lexicalised participle, here used substantivally, is therefore in my opinion the best interpretation from both a synchronic and a diachronic perspective.

If preṃtsa does continue ${ }^{*} b^{h}$ érontih $h_{2}$, the word constitutes a significant archaism within Tocharian. It is well known that the verbal stem ${ }^{*} b^{h} e r-e / o$ is continued in Tocharian as the present stem Bparo/e-, Apäro/e- 'carry, bring, take', one of the few thematic presents with direct cognates outside the branch; cf. Ringe (2000: 125) ${ }^{24}$ Outside the present, the verb is suppletive. In TA, the stem $k \bar{a} m \bar{a}$ - 'carry, take' expresses both the subjunctive and the preterite; in TB, kama- 'id.' forms only the preterite, while as- 'fetch' and ay- 'give' express the subjunctive. According to Schmidt (1974: 367 ), the meaning 'take' is predominantly found outside the present, and it therefore seems likely that it is a recent addition to the semantic sphere of PT *para/e-. The semantic development preṃtsa from PIE is therefore easily understood: 'carrying' (f.) $\rightarrow$ '(child-)bearing' $\rightarrow$ 'pregnant'; cf. Skt. bibharti 'to carry (a child)', Goth. berusjos 'parents', Germ. gebären 'give birth', Russ. berémennaja 'pregnant'.

24 This was noticed simultaneously by D. Ringe and J. Jasanoff; cf. Ringe (2000: 121 fn. 1). 
TABLE 4 Analogy in the plural of the $n t s a$-paradigm

\begin{tabular}{llll}
\hline & Pre-Proto-Tocharian & & Tocharian B \\
\hline nom.sg. & ${ }^{*}$-ntsa & $>$ & $-n t s a$ \\
obl.sg. & ${ }^{*}-n t s a$ & $\rightarrow$ & $-n t s a i$ \\
& & & \\
nom.pl. & $*$-ntań & $\rightarrow$ & $-n t s a \tilde{n}$ \\
obl.pl. & $*-n t a n$ & $\rightarrow$ & $-n t s a m$ \\
\hline
\end{tabular}

The development I am proposing took place in three steps. First, the feminine * $n t$-participle was restricted in use to female-specific occupations, e.g., *wapantsa 'weaving (f.nom.sg.)' $\rightarrow$ 'female weaver', while the masculine took over as the productive agentive formation for both grammatical genders. Such a development can explain why descendants of the PIE *nt-participle surface in Tocharian as agent nouns without additional derivational suffixes. The disintegration of gendered inflection was the key development that took the formation from primarily adjectival to primarily substantival. At this stage, the stem allomorph in the singular * $n t s$ - replaced * $n t$ - in the plural; cf. Table $4 .{ }^{25}$

Secondly, the $n t s a$-forms lost their specifically female reference and were reinterpreted as agent nouns forming occupational titles: *wapantsa 'female weaver' $\rightarrow$ 'weaver'. The existence of Awäpämtsune 'weaving' indicates that this happened in Pre-PT. The third step is only evidenced by TB, namely that the $n$ tsa-suffix became productive to form occupational titles.

The development from feminine to epicene agent noun may appear counterintuitive, but it does have several parallels, especially on the lexical level. For instance, Danish sygeplejerske 'nurse' is overtly marked with the feminine agent noun suffix -ske (cf. syerske 'seamstress', morderske 'murderess'), but is used generally regardless of gender. The same is true for Dutch secretaresse 'secretary, administrative assistent' and kassière '(shop) cashier', to which the masculine

25 Since the expected feminine plural ${ }^{*}$-nta is formally identical to the $n t a$-agent noun in the nominative, it could be tempting to derive the latter from the former. Semantically, however, there is nothing that suggests an original feminine origin for the agent nouns in -nta, unlike those in -ntsa. In addition, one would have to explain why a plural developed into a singular. Deriving -nta from the masculine singular is thus in my opinion much easier. 
counterparts show a different meaning: secretaris 'administrative member of a board or organization', kassier 'bank teller, treasurer'.

A more systematic parallel can be found in English, namely in the suffix $\mathrm{OE}$ -estre (> ModEng. -ster). While there has been quite a lot of scholarly debate over the origin and meaning of this suffix (cf. Peterson 2013 for references), the attestations indicate that the suffix was used almost exclusively to form feminine agent nouns in Old English: e.g., lērestre 'female teacher', hoppestre 'female dancer', webestre 'female weaver'. At this time, the only agent nouns in -estre with masculine reference were "renderings of Latin designations of men exercising functions which among the English were peculiar to women, as byrdistrce embroiderer (gl. blaciarius, primicularius), bcecestre baker (gl. pistor), sēamestre tailor (gl. sartor), wcescestre washer (gl. fullo)" (OED Online 2021: s.v. -ster). ${ }^{26}$ Support for the original feminine status of the suffix can be found in Dutch, where it is continued as the marked feminine counterpart of the unmarked agent noun suffix - er: ${ }^{27}$ werker 'worker' werkster 'female worker', gebruiker 'user' gebruikster 'female user'. In Middle English, from the 11th century CE onwards, forms like baxter 'baker' and webster 'weaver' began to be used as titles next to male personal names and as surnames; cf. Liueger se Bacestere (before 1093), John le Webestere (1275) (Hanks, Coates, \& McClure 2016: 170, 2853). Only much later, from the 17 th century CE, did female occupations begin to be remade with the borrowed feminine marker -ess, showing the loss of feminine connotation for -ster, e.g., seamstress, spinstress, songstress. Finally, the suffix -ster found moderate productivity as a denominal agent noun suffix ('someone to do with/working with X'): e.g., trickster, gangster, hipster.

On the lexical level, the similarity between English and Tocharian suffixes is quite striking. The agent noun wapantsa 'weaver' has the direct Middle English parallel webster 'id., while naskantsāna* 'female spinners' with its overt feminine marking can be taken as equivalent of the antiquated English form spinstress. Lastly, forms like lāntsa 'queen' and preṃtsa 'pregnant', which kept their feminine gender reference through specialisation of meaning, can be com-

26 Certain inanimate nouns with a similar suffix are also attested in Old English, e.g., eowestre 'sheepfold', heolstor 'hiding place'. This is present in other Germanic languages as well, e.g., Got. awistr 'sheepfold', hulistr 'veil', gilstr 'tribute, tax', ON hulstr 'sheath, case', blómstr 'flower', OHG gelstar 'tribute, tax' (Peterson 2013:3). Due to the difference in function, it is difficult to tell whether and how this suffix is related to agentival -ster. was borrowed from Latin -ärius; cf. Davis (1992: 103-104), Ringe \& Taylor (2014: 138). For a different explanation, see Gąsiorowski (2017) who takes both -er and -ster as derivatives of a feminine suffix ${ }^{*}-s(o) r$. 
pared to Modern English spinster, originally referring to a female spinner, now 'single woman past the typical age of marriage'.

An important caveat to this hypothesis was noted by G.-J. Pinault (p.c.), namely that weaving is not universally a female profession and that there are in fact examples of Central Asian cultures in which it is considered primarily a male occupation. ${ }^{28}$ Since the development proposed here has to be placed in the Pre-PT period, the sociolinguistic circumstances surrounding it are by default speculative. However, one important observation is that textile and food production belong both to the general sphere of housekeeping, as well as to commercial enterprise, which cross-culturally tends to be divided along gender lines. When predominantly female household occupations, such as cooking and weaving, become commercialised, men tend to take over the means of production (Minturn 1996; O'Brian 1999). The fact that these occupations are not strictly female, but rather show a tendency to shift from female to male, motivates the development from marked feminine agent noun to unmarked agent noun in these types of professions.

One of the formal aspects of the $n t s a$-forms which has yet to be discussed is the fact that they are seemingly derived exclusively to subjunctives of class [5] with stem vowel -a-. In this way, they differ from the ñca-forms, which are exclusively derived from the present stem, and the $n t a$-forms, which are derived from both the subjunctive and the present. There is good reason to assume that these two suffixes have the same origin, and that -nta represents a more archaic stage of -ñca originating from the masculine * $n t$-participle. This is best exemplified by the pair weñenta 'speaker, orator' weșșeñca 'speaker, speaking. Synchronically in TB, weñenta looks like it is derived from the sub-

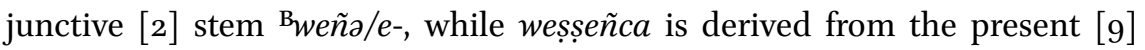
stem ${ }^{\mathrm{B}}$ weșşa/ske-. This present is not of PT date in light of the TA suppletive present stem tränk-; it was most likely created in Pre-TB, relegating the original present weña/e- to the subjunctive (Winter 1977: 134-135; Malzahn 2010: 343-344). The agent noun weñenta must have been lexicalised before the new present was created, thereby explaining the apparent affinity with the subjunctive. I think that a similar explanation can be applied to the case of -ntsa. The form mall[a]ntsasmem is not built to any known stem of the verb ${ }^{\mathrm{B}}$ mala'oppress', which is only attested with a present of class [10]: ${ }^{\mathrm{B}}$ mallașs/sk-. The geminate of mallantsa* suggests that the form continues the archaic unextended nasal present stem PT * mal-n-a- with assimilation of the nasal of the

28 For instance, in the pre-industrialized Uzbekistan of 1926, $98.2 \%$ of weavers were male (Sacks 1992: 188). 
suffix, possibly even going back to PIE * $m l-n-h_{2}-;$ cf. Hackstein (1995: 316). ${ }^{29}$ Similarly, ${ }^{B}$ naska- 'spin' must reflect an old derived present in *-sk- if to PIE *(s)neh ${ }_{1}$ - 'spin'; cf. $\operatorname{LIV}_{2}$ (571-572). The possibility of original aorist participles is also present in light of lāntsa 'queen' < *ulH-nt-ih $h_{2}$; cf. section 4. From a few forms in stem-final - $a$ - (e.g., *malla-ntsa, *wapa-ntsa, *naska-ntsa), the suffix could have become productive in subjunctive $[5] .^{30}$

As for the inflection nom.sg. - $a$, obl.sg. - $a i$, nom.pl. -añ, which cannot be original in either -nta or -ñca, Hilmarsson (1987:42) suggests that it spread from root nouns with final laryngeal, found as final member in verbal governing compounds of the type ${ }^{\mathrm{B} k a ̈ r t s e-r i t a}$ 'seeker of the good'. It has been argued that the rita-type compounds were not influential enough on their own to be the nucleus of the agentive $a$-inflection; cf. Malzahn (2010: 488): "there is no productive agentive suffix * $\bar{a}$ in Tocharian." If, however, the feminine * $n t$ participle with endings ${ }^{*}-a,{ }^{*}-a i$ had developed into an agent noun while the masculine was still a real participle, the basis for an agentive $a$-inflection would be more considerable. Eventually, the masculine was also transferred to this declension. The lexicalised $n t a$-forms would have been incorporated into this declension before - $\tilde{n} c$ - spread throughout the paradigm in the productive participle, so that they preserved the unpalatalized variant; cf. Ringe (1991: $96 \mathrm{fn}$. 85), Malzahn (2010: 491).

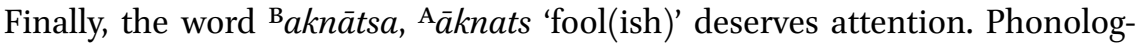
ically, the word resembles the $n t s a$-nouns, while syntactically and morphologically it behaves like ${ }^{\mathrm{B}_{-}} \tilde{n} c a$ and ${ }^{\mathrm{A}-n t}$, i.e., it functions as both adjective and substantive, it has both female and male reference, and it inflects according to the same declension. It is therefore no coincidence that diachronic accounts of the agent nouns take this word into consideration in one way or another.

29 But differently $\mathrm{LIV}_{2}\left(43^{2-433)}\right.$.

30 In light of Apekant 'painter', derived from the subjunctive stem PT *paika-, Bpaikāntsa 'painter' must be an innovation replacing an earlier nta-agent noun. This could have easily happened when -ntsa became productive as an epicene occupational suffix. 
TA substantival use, feminine reference ${ }^{31}$

/// mätne āknats mätne trikșant mät(n)e p///

A 80 a 4

'As if a fool, as if mistaken, as if ...'

TB adjectival use, masculine reference

walo aknātsa su märsau șañ āñm atsaik ñem araṇe- ${ }^{a}{ }^{3} m i$

THT 81 a2-3

'The foolish king, by the name Aranemi, having forgotten even himself'

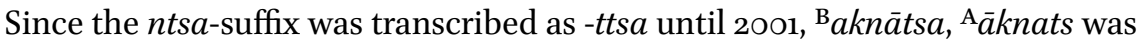
interpreted as a member of that class in all the traditional handbooks; cf. section 2. With this connection broken, both Hackstein (2012: 156-157) and Pinault (2012: 187) take *aknatsa as a privative abstract going back to PIE

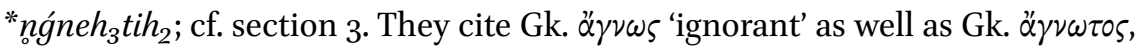
Skt. ájñāta-, Lat. ignōtus 'unknown' as related deverbal nouns to an original PIE base * $n$-ǵneh $h_{3}-t$ - As pointed out by Pinault (2012: 187), the formation looks very archaic within Tocharian: in PT, the building blocks (namely privative * $a$ and the verbal root *-kna-) were probably not available for productive use, so *aknatsa therefore looks older than PT. Semantically, the transition from abstract *aknatsa 'ignorance' to participant noun 'ignorant (one)' on a lexical basis is acceptable.

However, explaining ${ }^{\mathrm{B}} a k n \bar{a} t s a,{ }^{\mathrm{A}} \bar{a} k n a t s$ as an archaic feminine * $n t$-participle is also a possibility. Like ${ }^{\mathrm{B}}$ lāntsa, ${ }^{\mathrm{A}}$ lämts, the form would then be a relic of a PIE root aorist. On both the formal and functional sides, this suggestion does face some hurdles. First of all, one has to explain the lack of a nasal in the suffix. One possibility is that the form arose through dissimilation of nasals. ${ }^{32}$ Reconstructing the PIE active feminine participle of the root aorist of * gineh ${ }_{3}$ with a privative prefix forwards into PT would look like this: ${ }^{*} n-g n_{0} h_{3}-n t-i h_{2}>$ *enknantsa. Under these circumstances, with three nasals in successive syllables, it is conceivable that the third nasal was dropped by dissimilation. Secondly, one must account for the fact that ${ }^{\mathrm{B}} a k n \bar{a} t s a,{ }^{\mathrm{A}} \bar{a} k n a t s$, unlike ${ }^{\mathrm{B}}$ premtsa

31 Line spoken by Bhadrā, referring to herself; cf. Sieg (1952: 16-17).

32 This possibility was suggested to me by Michaël Peyrot (p.c.). 
and ${ }^{\mathrm{B}} / \bar{a} n t s a,{ }^{\mathrm{A}} / \bar{a} m \underline{t} t s$, does not have any particular semantic affinity with the feminine. Perhaps the dissimilation itself motivated the semantic change. If *aknantsa became *aknatsa, the link to the participial paradigm would have been weakened considerably. Later in Tocharian, any reintegration effort would be impossible due to the elimination of athematic /NTa/-forms on one hand ${ }^{33}$ and the further development of *-ntsa on the other.

\section{Conclusion}

In conclusion, there is a case to be made that the TB agent noun in -ntsa continues the PIE feminine active participle in *-nt-i $h_{2}$. This is substantiated partly by occupational $n t s a$-nouns pertaining to female professions and partly by the relic forms premtsa 'pregnant' and lāntsa 'queen'. Under this hypothesis, it can be explained why the TB agentive formations with suffixes in /-NTa/ do not show gendered inflection, even though they continue the PIE *nt-participle. In fact, the assumption that gendered inflection was lost helps explain why they began to develop into agent nouns. A further conclusion is that all three TB agent nouns in /-NTa/ can be explained from a single paradigm which underwent two splits: one in Pre-PT leading to the lexicalisation of -ntsa, and one in Pre-TB leading to the lexicalisation of - $n t a$ and the phonological renewal of -ñca. This scenario is compatible with the simpler system in TA, which has a two-way contrast between -nts (cf. wäpamts* 'weaver') and productive - $n t$. From a phylogenetic point of view, this also means that the Tocharian branch aligns with Core Indo-European in having inherited a participle in * ${ }^{*} n t$ - with active voice and gendered inflection.

33 The TB ñca-forms seem only to be created productively to thematic present stem classes [2], [8], [9], and [10]. Very few athematic forms exist: mäskeñca 'being' to prs.[3] ${ }^{\mathrm{B}}$ maske'be(come)', śawāñnca 'eater, eating' to prs.[5] 'śswá- 'eat'. The form yneñca 'goer, going' seems to be formed from the thematic variant yane- (cf. prs.1pl. ynem, 3pl. yanem) of the otherwise athematic prs.[1] B $y(n)$ - 'go' (Malzahn 2010: 355-356). There are no ñca- or $n t a-$ forms attested to present class [6], a curious fact since the verbs of this class are numerous and predominantly transitive. The role of productive agent noun is instead filled by the suffix - uca added to the subjunctive stem. It is highly likely that these two facts are related; cf. the proposal by Itkin \& Kuritsyna (2020: 97). 


\section{Acknowledgments}

This paper is adapted from a presentation given at the online conference "Tocharian in Progress" at Universiteit Leiden on 10 December 2020. I would like to thank the participants at the conference for their helpful comments, as well as Michaël Peyrot (Leiden), Sasha Lubotsky (Leiden), Federico Dragoni (Leiden), and Paulus van Sluis (Leiden) for input and advice during the writing process. I am also grateful to the anonymous reviewers for their constructive feedback. The research was conducted as part of the project "The Tocharian Trek", financed by the European Research Council (ERC-2017-STG 758855).

\section{References}

Adams, Douglas Q. 2013. A dictionary of Tocharian B. Revised and greatly enlarged. 2 vols. Amsterdam \& New York: Rodopi.

Adams, Douglas Q. 2015. Tocharian B. A grammar of syntax and word-formation. Innsbruck: Institut für Sprachen und Literaturen der Universität Innsbruck.

Adams, Douglas Q. 2017. The lexicon of Tocharian. In Handbook of comparative and historical Indo-European linguistics, ed. Jared S. Klein, Brian Joseph, \& Matthias Fritz, 1365-1388. Berlin \& Boston: de Gruyter Mouton.

Carling, Gerd. 2003. New look at the Tocharian B medical manuscript IOL Toch 306 (Stein Ch.oo316.a2) of the British Library-Oriental and India Office Collections. Historische Sprachforschung 116: 75-95.

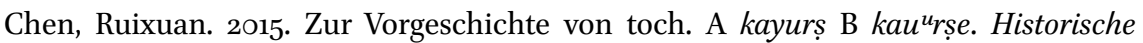
Sprachforschung 128: 5-10.

Chen, Ruixuan. 2019. Vignettes of Buddhist asceticism. Jottings on six fragments in Tocharian B. Central Asiatic journal 61/2: 217-256.

Ching, Chao-jung. 2010. Secular documents in Tocharian. Buddhist economy and society in the Kucha region. Ph.D. dissertation, École Pratique des Hautes Études.

Ching, Chao-jung. 2013. Reanalyzing the Kuchean-Prākrit tablets THT4059, THT4062 and SI P/141. Tocharian and Indo-European studies 14: 55-94.

Ching, Chao-jung \& Hirotoshi Ogihara. 2010. Internal relationships and dating of the Tocharian B monastic accounts in the Berlin collection. Studies on the Inner Asian languages $25 \cdot 75^{-141}$.

Ching, Chao-jung \& Hirotoshi Ogihara. 2020. Qiūcíshíkū tíji [Cave inscriptions in ancient Kucha]. Shànghăi: Zhōngxī Shūjú.

Clauson, Gerard. 1972. An etymological dictionary of pre-thirteenth-century Turkish. Oxford: Clarendon Press.

Couvreur, Walter. 1955. Die Fragmente Stein Ch. oo316 a2 und Hoernle H 149. 47 und 213. Zeitschrift für vergleichende Sprachforschung 72: 222-226. 
Davis, Garry W. 1992. OE -estre and PGmc. *-ārjaz. The origin and development of two agentive suffixes in Germanic. American journal of Germanic linguistics and literatures 4/2: 103-116.

Del Tomba, Alessandro. 2020. The Tocharian gender system. A diachronic study. Ph.D. dissertation, Universiteit Leiden \& Sapienza-Università di Roma.

Dietz, Rudolf. 1981. Der Gebrauch der Partizipia Präsentis im Tocharischen. Eine syntaktische Untersuchung. Ph.D. dissertation, Goethe-Universität Frankfurt am Main.

Edgerton, Franklin. 1953. Buddhist Hybrid Sanskrit grammar and dictionary. Volume II: Dictionary. New Haven: Yale University Press.

Fellner, Hannes A. 2014a. The Tocharian adjectives in B -tse A -ts. In Proceedings of the 25th Annual UCLA Indo-European Conference, ed. Stephanie W. Jamison, H. Craig Melchert, \& Brent Vine, 49-56. Bremen: Hempen.

Fellner, Hannes A. 2014b. Tocharian special agents. The $n t$-participles. Tocharian and Indo-European studies 15: 53-67.

Fellner, Hannes A. 2017. The syntax and semantics of agent formations in Tocharian. In Verbal adjectives and participles in Indo-European languages. Proceedings of the conference of the Society for Indo-European Studies, Paris, 24th to 26th September 2014, ed. Claire Le Feuvre, Daniel Petit, \& Georges-Jean Pinault, 73-84. Bremen: Hempen.

Fellner, Hannes A. \& Laura Grestenberger. 2018. Die Reflexe der *-nt- und *-mh ${ }_{1}$ no-Partizipien im Hethitischen und Tocharischen. In 100 Jahre Entzifferung des Hethitischen. Morphosyntaktische Kategorie in Sprachgeschichte und Forschung. Akten der Arbeitstagung der Indogermanischen Gesellschaft vom 21. bis 23. September 2015 in Marburg, ed. Elisabeth Rieken, 63-82. Wiesbaden: Reichert.

Gąsiorowski, Piotr. 2017. Cherchez la femme. Two Germanic suffixes, one etymology. Folia linguistica historica 38: 125-147.

Hackstein, Olav. 1995. Untersuchungen zu den sigmatischen Präsensstammbildungen des Tocharischen. Göttingen: Vandenhoeck \& Ruprecht.

Hackstein, Olav. 2012. Collective and feminine in Tocharian. In Linguistic developments along the Silk Road. Archaism and innovation in Tocharian, ed. Olav Hackstein \& Ronald I. Kim, 143-177. Wien: Verlag der Österreichischen Akademie der Wissenschaften.

Hackstein, Olav. 2017. The phonology of Tocharian. In Handbook of comparative and historical Indo-European linguistics, ed. Jared S. Klein, Brian Joseph, \& Matthias Fritz, 1304-1335. Berlin \& Boston: de Gruyter Mouton.

Hanks, Patrick, Richard A. Coates, \& Peter McClure. 2016. The Oxford dictionary offamily names in Britain and Ireland. Oxford: Oxford University Press.

Haspelmath, Martin. 1994. Passive participles across languages. In Voice. Form and function, ed. Barbara A. Fox \& Paul J. Hopper, 151-177. Amsterdam: Benjamins.

Hilmarsson, Jörundur. 1987. The element -ai- in the Tocharian nominal flexion. Die Sprache 33: 34-55. 
Hilmarsson, Jörundur. 1991. The nasal prefixes in Tocharian. A study in word formation. Reykjavík: Málvísindastofnun Háskóla Íslands.

Itkin, Ilya B. \& Anna V. Kuritsyna. 2020. Again on nomina agentis in Tocharian B. Some new observations. Tocharian and Indo-European studies 20: 84-106.

Jasanoff, Jay H. 1998. The thematic conjugation revisited. In Mír curad. Studies in honor of Calvert Watkins, ed. Jay H. Jasanoff, H. Craig Melchert, \& Lisi Oliver, 301-316. Innsbruck: Innsbrucker Beiträge zur Sprachwissenschaft.

Jasanoff, Jay H. 2018. The phonology of Tocharian B okso 'ox'. In Farnah: Indo-Iranian and Indo-European studies in honor of Sasha Lubotsky, ed. Lucien van Beek, Michiel de Vaan, Alwin Kloekhorst, Guus Kroonen, Michaël Peyrot, \& Tijmen Pronk, 72-78. Ann Arbor: Beech Stave.

Ji Xianlin, Werner Winter, \& Georges-Jean Pinault. 1998. Fragments of the Tocharian A Maitreyasamiti-Nātaka of the Xinjiang Museum, China. Transliterated, translated and annotated by Ji Xianlin in collaboration with Werner Winter \& Georges-Jean Pinault. Berlin \& New York: de Gruyter.

Klingenschmitt, Gert. 1975. Tocharisch und Urindogermanisch. In Flexion und Wortbildung. Akten der V. Fachtagung der Indogermanischen Gesellschaft, Regensburg, 9.-14. September 1973, ed. Helmut Rix, 148-163. Wiesbaden: Reichert.

Krause, Wolfgang. 1952. Westtocharische Grammatik. Band I: Das Verbum. Heidelberg: Winter.

$L I V_{2}=$ Rix, Helmut et al., eds. 20o1. Lexikon der indogermanischen Verben. Die Wurzeln und ihre Primärstammbildungen ${ }^{2}$. Wiesbaden: Reichert.

Lubotsky, Alexander. 1994. The original paradigm of the Tocharian word for 'king.' In Tocharisch. Akten der Fachtagung der Indogermanischen Gesellschaft, Berlin, September 1990, ed. Bernfried Schlerath, 66-72. Reykjavík: Málvísindastofnun Háskóla Íslands.

Malzahn, Melanie. 2010. The Tocharian verbal system. Leiden \& Boston: Brill.

Maue, Dieter. 2015. Alttürkische Handschriften. Dokumente in Brāhmī und tibetischer Schrift. Teil 2. Stuttgart: Steiner.

Mayrhofer, Manfred. 1992. Etymologisches Wörterbuch des Altindoarischen. Band I. Heidelberg: Winter.

Melchert, H. Craig. 1983. A "new" PIE *men suffix. Die Sprache 29/1: 1-26.

Melchert, H. Craig. 2003. Hittite nominal stems in -anzan-. In Indogermanisches Nomen. Derivation, Flexion und Ablaut. Akten der Arbeitstagung der Indogermanischen Gesellschaft, Freiburg, 19. bis 22. September 2001, ed. Eva Tichy, Dagmar S. Wodtko, \& Britta Irslinger, 129-139. Bremen: Hempen.

Minturn, Leigh. 1996. The economic importance and technological complexity of handspinning and hand-weaving. Cross-cultural research 30/4: 330-351.

O'Brian, Robin. 1999. Who weaves and why? Weaving, loom complexity, and trade. Cross-cultural research 33/1: 30-42. 
OED Online 2021:s.v. -ster. Oxford English dictionary. https://www.oed.com/view/Entry/ 189877?result=1\&rskey=H4VWSW\& (accessed 13 August 2O21).

Ogihara, Hirotoshi. 2012. Tokarago B "Avadāna shahon" ni tsuite [On the "Avadāna manuscript" in Tocharian B]. Tōkyō Daigaku gengogaku ronshū [Tokyo University linguistic papers] 32: 109-243.

Ogihara, Hirotoshi. 2015. Kuchean verses written on a wooden tablet kept at Xinjiang Kucha Academy. In Tocharian texts in context. International conference on Tocharian manuscripts and Silk Road culture held June 26-28, 2013 in Vienna, ed. Melanie Malzahn, Michaël Peyrot, Hannes A. Fellner, \& Theresa-Susanna Illés, 149-157. Bremen: Hempen.

Peterson, Paul. 2013. An old problem in etymology revisited. The origin of Germanic nouns with the suffix -ster. Amsterdamer Beiträge zur älteren Germanistik 70: 120.

Peyrot, Michaël. 2008. Variation and change in Tocharian B. Amsterdam \& New York: Rodopi.

Peyrot, Michaël. 2010. On the formation of the Tocharian preterite participle. Historische Sprachforschung 121: 69-83.

Peyrot, Michaël. 2017. On the part of speech and the syntax of the Tocharian present participle. In Verbal adjectives and participles in Indo-European languages. Proceedings of the conference of the Society for Indo-European Studies, Paris, 24th to 26th September 2014, ed. Claire Le Feuvre, Daniel Petit, \& Georges-Jean Pinault, 327-341. Bremen: Hempen.

Peyrot, Michaël, Georges-Jean Pinault, \& Jens Wilkens. 2019. Vernaculars of the Silk Road-A Tocharian B-Old Uyghur bilingual. Journal asiatique 307/1: 65-9o.

Pinault, Georges-Jean. 1989. Introduction au tokharien. LALIES $7,5^{-224}$.

Pinault, Georges-Jean. 2008. Chrestomathie tokharienne. Textes et grammaire. Leuven \& Paris: Peeters.

Pinault, Georges-Jean. 2012. Tocharian -nt- participles and agent nouns. In Linguistic developments along the Silk Road. Archaism and innovation in Tocharian, ed. Olav Hackstein \& Ronald I. Kim, 179-204. Wien: Verlag der Österreichischen Akademie der Wissenschaften.

Pinault, Georges-Jean \& Hirotoshi Ogihara. 2010. Un fragment de planchette de bois en tokharien B. Journal Asiatique 298/1: 173-202.

Ringe, Donald A. 1991. Evidence for the position of Tocharian in the Indo-European family? Die Sprache 34: 59-123.

Ringe, Donald A. 1996. On the chronology of sound changes in Tocharian. Volume 1: From Proto-Indo-European to Proto-Tocharian. New Haven: American Oriental Society.

Ringe, Donald A. 200o. Tocharian class II presents and subjunctives and the reconstruction of the Proto-Indo-European verb. Tocharian and Indo-European studies 9: 121-142. 
Ringe, Donald A. \& Ann A. Taylor. 2014. A linguistic history of English. Volume II: The development of Old English. Oxford \& New York: Oxford University Press.

Sacks, Michael Paul. 1992. Work force composition, patriarchy, and social change. In Geographic perspectives on Soviet Central Asia, ed. Robert A. Lewis, Robert R. Churchill, \& Amanda Tate, 181-207. New York: Routledge.

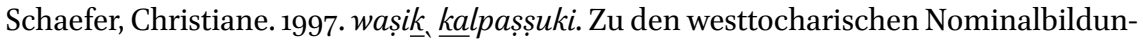
gen auf -uki. Tocharian and Indo-European studies 7: 163-176.

Schmidt, Klaus T. 1974. Die Gebrauchsweisen des Mediums im Tocharischen. Ph.D. dissertation, Georg-August-Universität Göttingen.

Schmidt, Klaus T. 1975. Zu einigen Problemen der tocharischen Verbal- und Nominalflexion. In Flexion und Wortbildung. Akten der V. Fachtagung der Indogermanischen Gesellschaft, Regensburg, 9.-14. September 1973, ed. Helmut Rix, 287-295. Wiesbaden: Reichert.

Schmidt, Klaus T. 2001. Entzifferung verschollener Schriften und Sprachen. Dargestellt am Beispiel der Kučā-Kharoșțhī Typ B und des Kučā-Prākrits. Göttinger Beiträge zur Asienforschung 1: 7-27.

Sieg, Emil. 1952. Übersetzungen aus dem Tocharischen II. Aus dem Nachlass herausgegeben von Werner Thomas. Berlin: Akademie-Verlag.

Sieg, Emil. 1955. Die medizinischen und tantrischen Texte der Pariser Sammlung in Tocharisch B. Zeitschrift für vergleichende Sprachforschung 72: 63-83.

Sieg, Emil \& Wilhelm Siegling. 1953. Tocharische Sprachreste. Sprache B. Heft 2: Fragmente Nr. 71-633. Ed. Werner Thomas. Göttingen: Vandenhoeck \& Ruprecht.

$T E B_{1}=$ Krause, Wolfgang \& Werner Thomas. 196o. Tocharisches Elementarbuch. Band I: Grammatik. Heidelberg: Winter.

Thomas, Werner. 1977. Ein weiteres tocharisches Udānavarga-Fragment. Zeitschrift für vergleichende Sprachforschung 90:104-113.

Wilkens, Jens. 2021. Handwörterbuch des Altuigurischen. Altuigurisch-Deutsch-Türkisch = Eski Uygurcanin el sözlüğ̈̈. Eski Uygurca-Almanca-Türkçe. Göttingen: Universitätsverlag Göttingen.

Van Windekens, Albert J. 1979. Le tokharien confronté avec les autres langues indoeuropéennes. Vol. II, 1: La morphologie nominale. Louvain: Centre International de Dialectologie Générale.

Winter, Werner. 1962. Nominal and pronominal dual in Tocharian. Language 38/2: 111134 .

Winter, Werner. 1977. Internal structure and external relationship of two verbal paradigms: Tocharian B weñ-, A weñ- 'say'. Journal of Indo-European studies 5: 133-159. 